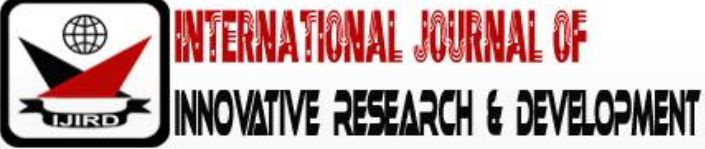

ISSN 2278 - 0211 (Online)

\section{Interrogating the Art of Developing Self-Learning Material for Open and Distance Learning (ODL) Students}

\author{
Cosmas Maphosa \\ Institute of Distance Education, University of Eswatini, Eswatini \\ Sithulisiwe Bhebhe \\ Faculty of Education, University of Eswatini, Eswatini \\ Talent Rugube \\ Institute of Distance Education, University of Eswatini, Eswatini
}

\begin{abstract}
:
Open and distance learning (ODL) thrives on students' utilisation of learning materials that designed in ways that allow them to learn on their own in the absence of a lecturer or tutor. This paper discusses what self-directed learning is and highlights the principles of writing self-learning materials for ODL learners. Various self-material materials utilised in open and distance learning are explored. In the paper, the writers further explore the nature, characteristics and importance of selflearning materials on ODL. The writers further discuss theories underpinning the utilisation of self-instructional materials. The paper further interrogates how learning material developers can engage in the effective development of self-learning materials in both print and electronic formats. Conclusions are drawn on the importance of professionally training material developers in developing high-quality self-learning materials for ODL learners.
\end{abstract}

Keywords: Distance education, learning materials, print material, electronic material, material development

\section{Introduction}

The success and effectiveness of open distance and learning (ODL) programmes depends on the design, development and utilisation of high-quality learning materials (Jayaram \& Dorababu, 2015). High-quality learning materials should be student-centred, considering the needs and interests of the student in ensuring that the student derives maximum benefit from their use Zabidi, Woo, Kumar, Fadzil, \& Husain (2017). Gbenoba and Dahunsi (2014) also note that "customised, self-instructional materials are at the heart of instructional delivery in Open and Distance Learning (ODL)". This further buttress the importance of effective design and development of instructional materials for open distance and e-learning students, in ways that enhances instructional delivery and maximises student attainment.

In web-based learning, for example, Conrad and Donaldson (2004) state that students on the web must be guided adequately in their learning and they must feel comfortable with a higher level of self-direction than in a traditional classroom. Availability of the much-needed direction in learning ensures that students will not quit online courses out of frustration.

Open, distance and learning (ODL), one most innovative concept in the history of education relies on self-learning materials developed by institutions for the purposes of teaching and learning (Hashim, 2010). The institutes that provide ODL programmes need to understand that the educational products and services they provide offer an encouraging educational experience for the learners Gbenoba and Dahunsi (2014). The main task of any distance education programme provider is to design and offer distance educational experience that encourages learning, thus, there is a need for the ODL programme providers to have the art of developing self-learning material to enhance student learning.

In ODL media and technology has been used in preparing self-learning material and to carry educational information and as instruments to bridge the distance between the lecturer and the student. The students pursue their studies self-sufficiently with little external support. Self-learning materials are designed and developed with the notion that they need to help the student study independently (Commonwealth of Learning, 2005).

\subsection{Nature of Open and Distance Learning}

ODL is a different way of learning as there is a physical distance between the student and the institution (UNISA, 2019). The achievement of a successful Open, Distance and Learning (ODL) programme in any institution depends on the availability of quality and quantity of learning materials availed to the students (Gbenoba \& Dahunsi, 2014). Self-Learning materials prepared for ODL become an important aspect of distance learning so much so that in most instances they serve the role of the instructors to the learners. According to Tezpur University (2018), the self-learning materials should not only impart knowledge to the learners but, should be in a state to inspire and provoke students to learn. The potential 
impact of distance learning on all education lies in the very use of self-instructional learning materials complemented by visual, auditory, audio-visual and multimedia content.

According to Study Portals (2016), distance learning has been around for a long time and has evolved in a significant number of ways. Open learning basically combines online education with flexible to no admission requirements. Similarly, Gosh, Nath, Agarwal, Nath and Chaudhuri (2012), express the view that ODL is a concept in education that came from an idea where the learners and the teachers cannot be in a classroom and they should be separated by some geographical distance or maybe they cannot come close to each other to make the entire education system flexible. The distance education is not a new concept.

\subsection{Principles of Writing Self-Learning Materials}

Chaudhary and Reddy (2018) has outlined the principals involved in the preparation of self-learning materials and aligned them to the synthesis of the theories of learning and the theories of communication. Learning theory is concerned with the process of acquiring knowledge, skills, and behaviour. Communication theories, as applied to education, with the forms and means of interaction between learners and teachers, guiding students on the presentation of content or discussion. Instruction involves gaining and controlling attention, stimulating recall, facilitating learning, providing feedback, arranging for remembering, and assessing outcomes.

Self-learning materials should motivate students; thus, they need to be prepared in such a way that they facilitate learning of the students, attract and sustain their attention on what is being discussed (Mart, 2011). There are a number of conditions that can attract the attention of students and the popular among them include change, novelty, and attractiveness of the materials that they use in their learning. These should motivate and provide students with a purpose and direction to follow as well as encouraging the students to read the attentively to achieving set individual goals (Dişlen, Ve, İfadeleri, Motivasyon \& Sosyal, 2013).

Developing self-learning material for open, distance and learning is vital to ensure that students learn and recall information as this is an essential condition to achieve effective learning outcomes (Khalil, 2016). Learning and recalling assists students understanding something new when they already know something related to the new information as this assists them to comprehend the concepts of the unit being studied. According to Luque (2017) previously acquired information guides students into new learning. Thus, developing self-help material that will allow the student to develop a skill of recall of previously acquired knowledge is essential.

Learning through self-learning materials may be guided through verbal or pictorial material that provides 'clues or hints' to new principles. According to Ramirez (2012,) new technologies have been put in place to allow new possibilities that will integrate multimedia visual aids to assist ODL students to fully exploit developed self-learning materials. This is a good way of guiding the students especially at the beginning or introduction stage of a text (Chaudhary, 2018).

Tullis and Benjamin (2011) points out that there is a need for students to get some feedback on their accomplishments as they are motivated to work with a clear direction on the path they are taking. This means that selflearning materials should have clearly defined objectives of instruction so that they become fully aware of what they are expected to do in order for them to succeed. The learners should know, while studying the unit, whether they are on the right track. Various provisions of providing feedback such as self-check questions exercises, assignments, academic counselling and tutorials can be thought of. In preparing self-learning materials, the outcomes of learning need to be assessed frequently and there should be a summary in every unit (Morrison, 2012)

There are a number of types of ODL institutes. Albuquerque and Prasad (2019) point out that in India the ODL institutes can be divided into Departments of Distance Education in an institute, Open Universities, Private institutions that offer distance learning programmes and Massive Open online course (MOOC). According to Surbhi (2014) in some universities there are departments of distance education where the university offers regular campus-based programs through the distance education mode where the students are not present in person at the site. In some instances, conventional universities offer various programmes through correspondence courses and thus set up Distance or Correspondence Courses Institutes (CCI). Distance Education is best in that it is offered with the purpose to allow access to education to those who are unable to attend the regular colleges. It is important that such students gain access to selflearning materials that would assist them in their reading (Jayaram \& Dorababu, 2015). A student studying through distance education does not have a direct face-to-face contact with the instructor, but can use various modes to access education, like e-learning, video conferencing and e-mail (Commonwealth ofLearning, ,2005). In the distance mode of education, the student is not required to attend the classes regularly, and the evaluation of his research work is done through the tests conducted at regular intervals (UNISA, 2019). Trembla, Lalancette and Roseveare (2012) reveal that distant education institutes offer library facilities and online information for their student. Students are given the opportunity to study on their own but they have to appear for the exam or test decided by the university before receiving a degree.

\subsection{Self-Directed Learning and Its Strategies}

Self-learning is the new form of learning that is equipping people with skills that are relevant to their daily activities. Self-learning is the modern form of learning and it requires the students to have self-learning materials to use in their own environments (Tezpur University,2018). This type of instruction has come in not to replace traditional, instructional learning, but to supplement it and in the most recent years great results have been realised through selfdirected learning. Hawkins ( , and fast ,convenient , directed learning has been proven to be effective-points out that self (2018 Goo .learning materials from all around the world-through the use of the internet which has allowed students to access selfgle 
search has given students an opportunity to do almost anything. Students are able to watch a YouTube tutorial, and by simply reading instruction manuals manage to do all they desire to do.

Through self-directed learning students develops strong problem-solving skills. Self-learning empowers students with the skills to identify problems and quickly look for effective solutions on their own. The solutions could come from other colleagues they meet through the internet or by exploration (Seyed, 2012). The challenges and obstacles students meet are meant to provide them with new opportunities to learn new things at their own pace and time in the places where they desire. Students get to learn how to actively look for solutions instead of having solutions brought to them through instruction from their lecturers or tutors (Dickson, 2018). Self-learning also assists the students to easily adapt to changes in the environment due to the ability to learn fast through the designed self-learning materials (Briggs, 2015)

Self-learning is a stress-free learning process. The process of self-learning places a great emphasis on the process rather than the outcome of the learning. Moreover, there is no pressure to learn the required content within a certain time, with the ultimate goal being the achievement of high grades. The student is given the freedom to choose what to learn when to learn, and how to learn (Seyed, 2012). Self-learning is a way to gain skills. Self-directed learning, assists students to learn other important skills such as time management, self-assessment, and setting own goals (Briggs, 2015). These are important skills that students need and may be able to apply anywhere. In fact, people who are good at self-learning have an increased ability to develop other skills and they learn how to stick to a plan until they achieve their goals.

Blaschke (2014) postulates that for an ODL student learning becomes more meaningful in self-directed learning when the student tackles tasks on their own and coming to understand his or her capabilities. Self-driven learning comes from a personal desire to gain new knowledge (Brighter, 2017). It is driven by the need to find more information about a topic and use the information for a particular purpose. Therefore, through self-directed learning, a student gains a clear purpose of learning and the information gained is often relevant, making it more meaningful. A student is also compelled to search for deeper information about a topic and give a purpose to learning, leading to the desired results.

According to Willis (2018,) self-directed learning is led by curiosity. Learning occurs naturally when there is curiosity. This, therefore, means that the student will be motivated to learn and will get to acquire much more knowledge when the drive comes from within than from outside sources. Learning becomes an adventure and the student's capabilities are expanded each time they successfully learn something new.

The student has the freedom to choose the mode of learning, they may use YouTube tutorials, webinars, books, or any other mode of learning that they are exposed to with the changing of technology. The students get to choose the one that suits them and their environment best and one that they find most engaging and the one that allows them to use the designed self-learning materials (Mahlangu, 2018).

\subsection{Unpacking Self-Learning Materials}

Barandika, Beitia, Ruiz-de-Larramendi and Fidalgo (2013:2) state that;

Self-learning is taking in information, processing it, and retaining it without the need for another individual to be teaching it in order for the understanding to occur.

It, therefore, means that self-learning materials should enable students to engage in meaningful learning on their own. Self-learning materials may also be referred to as self-teaching or self-instructional materials, which are materials designed in such a way that a student is able to work independently. Such material should be user-friendly and developed in a way that it is easy to use and ensure students understand the content and are able to achieve the desired learning outcomes. Kumari (2012) notes that learning material which is difficult to understand will contribute to students' dropping out of programmes of study.

Kumar (2016) further notes that self-learning materials are course materials specially designed and developed to enable students to study partly or wholly by themselves and where print modules are utilised as self-instructional materials, they "have been described as Tutorial-In-Print." This means that such material has to provide the student with full guidance in learning, in the absence of a course lecturer or tutor. The student should not struggle to master content when using self-learning materials of any type.

As espoused by Rahman (2015) self-learning materials are mainly designed for students to study on their own with limited or no assistance from a lecturer, tutor or peer. It is, therefore, important that content is structured, sequenced and presented in ways that make it easy for the student to understand. To this end, a well-developed self-learning material should include a lot of activities which motivate the student to study. As Rahman (2015) further notes, activities in a selflearning material are integrated and meant to mimic classroom-learning activities.

Self-learning materials are at the heart of instructional delivery in Open and Distance Learning (ODL) (Gbenoba \& Dahunsi, 2014). Commonwealth of Learning (2005) points out that ODL materials are sometimes prepared by individuals, but more often by small teams made up of people with skills such as curriculum design, instructional design, tutorial support and print or web design skills. Jayaram (2019:21930) reveals that;

Writing for distance education is a more challenging task and quite different from that face-to-face teaching or writing for a book or a journal. Self-learning materials depend on exploiting the various means and ways of communication to suit it to the needs of the learners. According to Gbenoba and Dahunsi (2014,) ODL study material is expected to imitate what the teacher does in the face-to-face learning environment, meaning that the learner should be able to learn with or without the support of the teacher. The material prepared should be self-explanatory, self-contained, self-directing, self-motivating and self-evaluating. The self-learning material should take such a nature because in most case the student time and again feels secluded in the absence of the teacher and peer-students.

Commonwealth of Learning (2005) points out that there are four principal ways in which learning materials are produced. These are by an instructional designer who is the content provider and the writer, by an instructional designer 
who commissions freelance content-providers to write the materials, by an instructional designer who converts text provided by a teacher or by a team of people, including content-providers, instructional designers and specialists such as audio and video producers. In the preparation of self-learning materials for ODL, Gbenoba and Dahunsi (2014) point out that study materials must take into account the significant proportion of students who enrol with little or no experience of distance study as this is common especially in developing countries.

The structure of material prepared for self-learning should maintain learner's interest. The structure must be clear to the learners and this will allow them to exert some control over how they learn. ODL students learn away from the institute, hence, may feel extremely isolated and a feeling of control is a great boost to self-confidence.

According to Minnesota State University (2019,) there is a need to set aside time to study as an ODL student. Distance learners need to know how much time to spend on a given learning package, when it is permissible to take a break in their studies and when they need to pick them up again. Open learners' study at their own pace (Somuah, Dankyi \& Dankyi, 2014). Those experienced in ODL will know, though, that completely open-ended study is rarely effective. Most learners will lose momentum at some stage and, without a truly pressing need to continue, will rarely pick things up again. Interaction, both learner-to-learner and learner-to-tutor, is another powerful method of ensuring learners maintain an appropriate pace, and judicious intervention by tutors can help motivate and encourage learners to keep going, but this is limited in ODL (UNISA, 2019). This may be possible with the knowledge and techniques of engaging in self-directed learning.

\subsection{Nature, Characteristics and Importance of Self-Learning Materials in ODL}

Self-learning materials also assist students to assess themselves. An integral component of self-learning material is the self-assessment and self-reflection exercises. Self-assessment enables students to obtain feedback on their learning and helps them improve their performance Boud and Falchikov (2007) in Rahman (2015) further notes that the use of assessment questions in a self-learning material may be necessary to motivate the student to continue to engage with the learning material. Assessment in self-learning materials should centre on the competencies to be developed because of learning and such competencies of the cognitive, psychomotor and affective nature.

The self-learning materials come in different forms. The self-learning material may consist of written content, whether on paper, for example, prescribed books or textbooks, or online material, for example, e-reserves, instead of listening to a teacher or lecturer in a classroom. In some instances, institutes may provide access to computers and the internet and there could be other partner organisations or centres where students may access information from (UNISA, 2019).

The use of the wide world web (www) is the most interesting development in the use of technology for education, for the delivery of course material and student-tutor interaction (AlGhamdi \& Junaidu, 2014). Most of the self-learning material prepared for ODL students is organized in the form of an electronic textbook or electronic course notes that the student can "read" at his/ her own pace. Some also provide multiple routes of navigation through the material, search facilities, integration of text, images, and video, user-interaction, and question-answer tests. Wallis (2017) points out that an online text for a business course was given merits for it being lighter, always accessible and seriously cheaper than print books.

The concept of open learning and distance education system focuses on open access to education and training to make the learners free from the constraints of time and place, and offering flexible learning opportunities to individuals and groups of learners (Gosh, Nath, Agarwal, Nath, \& Chaudhuri, 2012). On the same note Study Portals (2016) reveals the advantages of ODL as that, fewer admission requirements are needed, for example developing specific facilities for international or disabled students, a student is in a position to make their own schedule like not having to complete a programme within a specific time instead, learning at their own pace and making their own decisions about how they want to follow the programme. According to Endea $\mathrm{n}(2012$,) more and more students are finding themselves learning at a distance and the student has little need to travel and they can choose the courses they feel manageable for them to do.

Self-learning materials perform the functions of an effective teacher who guides, motivates, explains, discusses, asks questions, assesses progress, suggests appropriate remedial measures, and provides advice to learners, but the learner must be ready for learning (Tarhan \& Sesen, 2012). Self-learning materials for ODL students need to be clear so that students will understand why they have to undertake a task and how it fits into the curriculum (Jones, 2005). Selflearning materials emphasise pedagogical dialogues with the learner. While reading the course units, the learners interact with an invisible teacher. The materials also provide questions for self-check and thus increase the curiosity of the learners. The success of self-learning depends on the quality of the learning materials. Self-learning materials follow learner-centred approaches. They are designed and developed as per the needs of the learners (Koul, Ghaudhary, \& Sohanvir, 1989). The following are some of the characteristics of self-learning materials suggested by (Thompson, 2003).

\subsubsection{Self-Contained}

According to Koul, Ghaudhary and Sohanvir (1989), self-learning materials need to be made to make the text selfsufficient so that a student does not hunt for the additional source, or even a teacher. This means that the scope of the content of the unit is visualised in detail. While avoiding what is redundant only the essential details are presented so that the unit can cover information required by the student and keep away all that is superfluous or redundant.

\subsubsection{Self-Explanatory}

The self-learning material in ODL must be presented in a style that a learner can learn from the material without much external support. The concepts are explained to the extent that the majority of the learners are able to comprehend 
them. Therefore, the content is self-explanatory and conceptually clear. In order to make concepts self-explanatory the content is analysed and presented logically considering the mental and lingual background of the students' target group. A few may not be able to comprehend the contents fully and may, therefore, need additional help and guidance by teachers through correspondence and at study centre tutorials (Jayaram \& Dorababu, 2015).

\subsubsection{Self-Directed}

The self-learning materials aim at providing necessary guidance, hints and suggestions to the learners at each stage of learning. Fry, Ketteridge and Marshall (2008) describe self-directed material as that which is presented in the form of easy explanations, sequential development, illustrations, learning activities, etc., thus performing the role of a teacher who for instance guide, instruct, moderate and regulate the learning process in classroom situations.

\subsubsection{Self-Motivating}

In ODL education systems, the students remain off the campus for most of their study time. The study materials, like a teacher in the classroom, should be highly encouraging for the learners. The materials should arouse curiosity, raise problems, relate knowledge to familiar situations and make the entire learning meaningful for them, providing reinforcement and feedback at every stage of learning (Freeman, 2005).

\subsubsection{Self-Evaluating}

It is important for the designed self-learning materials to provide students with feedback as the learners remain separated from the distance learning institution as well as the teachers (Rahman, 2015). To ensure effective learning, the learners should know whether they are on the right track. Self-evaluation in the form of self-check questions, exercises, activities, provides the learners with the much-needed feedback about their progress, reinforces learning, and motivates them for self-learning (Yorke, 2003). The course writer should develop a built-in evaluation system by giving an appropriate number of self-check exercises, activities and questions in the course units.

\subsubsection{Self-Learning Principle}

Self-instructional materials are based on the principles of self-learning (Rakes \& Dunn, 2010). Therefore, in designing a leaning unit, the material developer should provide learners with useful information and guides, which will enable them to engage in independent learning. The learning material developer should also ensure that content provided in specific units is clarified and simplified by making use of simple explanations, examples, illustrations and activities (Driscoll, 2007). In other words, the materials are designed and, developed in such a way that the learners can undertake learning by oneself with occasional help from others including the teachers. Such an approach of designing learning materials is informed by a constructivist learning theory, which places emphasis on active learning on the part of the student (Gazi, 2009).

\section{Theorising the Utilisation of Self-Learning Material}

Understanding the role of self-learning material is underpinned by Mayer's cognitive theory of multimedia learning. The theory is based on three main assumptions. The first assumption is that there are two separate channels (auditory and visual) for processing information (Mayer, 2009). The second is that there is limited channel capacity and the last one is that and that learning is an active process of filtering, selecting, organizing, and integrating information (Mayer, 2009). Mayer's theory underscores the view that "people learn more deeply from words and pictures than from words alone" (Mayer, 2009:47). This point buttresses the importance of multi-media sources in open and distance learning. Print modules should be complemented by other electronic sources.

The development of self-learning materials may also be informed by the constructivist theory of learning. According to Tam (2000,) self-learning materials for distance learners should ensure that learners are self-motivated, selfdirected, interactive, and collaborative participants in their learning experiences by virtue of their physical location (Mai, Tse-Kian \& Xiao-Lian, 2007). To this end, learning material should assist in developing active, collaborative and responsible learners. A constructivist view of developing materials ensures the creation of active, constructive and meaningful learning and learner-motivated learning materials (Mai, Tse-Kian \& Xiao-Lian, 2007). Such material is practical, meaningful and exciting to learners.

\subsection{Developing Self-Learning Print Materials}

Jayaram (2019) points out that well-prepared self-learning materials should address the student as an individual, "You" should be addressed as "I", the learner should be 'you' (singular). The pronoun 'we' should be reserved exclusively for those occasions where you want to include both you and the learner. Jayaram ( 2019) further explains that in preparing self-learning material one should avoid the passive wherever possible as it distances the learner from what is going on. You can generally do so without resorting to the impersonal 'we' by making what you are discussing the subject of the sentence, use humour sparingly and give some thought to the diversity of your learners. This should not be a manifestation of political correctness, be careful of references which include especially assumptions about gender, race, language and history

\subsection{Developing Self-Learning Electronic Materials}

Print modules can be converted to e-modules, which can be made available through a learning management system and students are afforded the chance to download PDF formats of the entire module or sections of it. This will 
enable students to access the e-modules through the utilised Learning Management System in an institution of open distance and e-learning. LMS (Learning Management System) Moodle was established at faculties that have educational studies institution and was mainly used for communication and a file repository. Krašna and Bratina (2014) state that learning material developers may rework their PowerPoint presentation slides to make them text narrated, sound or video narrated learning materials.

\subsection{Developing Screencasts}

To produce online material that keeps learners engaged, screencasts can be used to accomplish the task. Screencasts are video recordings of screen activities (Peterson, 2007). They are visual such that students can see and follow through a process. Screencasts can be supplemented with an audio recording. Besides their interactive features, screencasts can be developed and used in low bandwidth environment, which facilitates knowledge sharing (MacLeod, Bergen, \& Storey, 2017) and enhances the provision of online resources (Pappas, 2018). Additionally, screencasts can be developed and used with learning management systems. It is no longer necessary to invest in expensive cameras and production studios (Roslinda, Asrina \& Siti, 2017). Online practitioners can embrace advances in technology and take advantage of screen recorders on mobile platforms such as Android, then develop screencasts anytime and anywhere. Screencasts have been developed for use in science education particularly mathematics (Soto \& Ambrose, 2016).

\subsection{Developing Podcasts}

According to Flood, Hayden, Bourke, Gallagher and Maher (2017) podcasts are audio or video files that are distributed via the Internet for use on personal computers and portable media devices. Podcasts or a series of audio or video recordings are useful in developing students' listening, research and writing skills and are vital in enabling the development of effective speaking and problem-solving skills in students (Salmon, Edirisingha, Mobbs, Mobbs, \& Dennett, 2008).

The use of podcasts has revolutionised teaching and learning by producing content, capturing live classroom material, and improving students' study skills (Salmon et al., 2008). Through podcasts learning the material is made accessible when students require it and students are afforded the opportunity to continuously replay the material for enhanced understanding (O'Neill, 2009). O'Neill (2009) further notes that for students whose first language is not English, the use of podcasts enables them to enhance understanding and internalisation of content through repeated listening. The other advantage of podcasts, according to O'Neill (2009) students have a chance to catch up on missed lectures by simply downloading lecture recordings. Critical elements important in developing a podcast is ensuring that the target audience is defined and clear learning outcomes are stated. Language use should be in such a way that students are able to follow and understand the content. Podcast developers are advised to keep things simple and keep podcasts short. Podcasts should capture students' attention. Where possible podcasts should also be activity-based in order to actively involve students in the learning process.

\subsection{Live Lecture Recording}

Live lecture recording, also referred to as lecture capture, is described as a way of recording lecture material to support students (Johri \& Olds, 2014). Lectures are recorded and viewed online. Ferriday, (2015) further state that lecture capture technology records the presenter's audio and video, as well as any visual aids - laptop, tablet, whiteboard, document camera, visualizer - synchronizes them, and webcasts the stream live or archives for on-demand playback (Dona, Gregory, \& Pechenkina, 2017). Recorded lectures offer flexibility, enhanced learning as learners with different learning styles are catered for. Moreover, if students fail to turn up for a lecture, they can play back the recorded lecture and catch up on what they have missed.

Kent, Ellis, Latter and Peaty (2018) state that design considerations of lecture recordings should include captioning. Lecture capture system should not be limited and should capture all important aspects of the lecture that is including the teaching area white board, smart board, PowerPoint screen, audience). Furthermore, lecture recording systems should enable users to access the system without time and space constraints; minimise the operational burden on academics; integrate with learning management system; easy to deploy and maintain (Anh, Nishantha, Hayashida, \& Davar, 2010).

\subsection{Flipped Classroom}

The flipped classroom is based on four principles based on developing students' understanding of factual knowledge in the context of a conceptual framework (Graziano, 2017). According to Chen Hsieh, Wu and Marek (2017) the flipped classroom approach provides an opportunity for students to be acquainted with coursed content before coming to class, students are provided with sufficient motivation to prepare for class and there is provision to assess students' understanding and students are engaged in activities that promote higher cognitive skills. A flipped classroom approach is a learner-centred one, in which students are actively involved in knowledge construction (Kong, 2014).

\section{Conclusions}

The study concludes that open, distance and learning (ODL) should be hinged on self-directed learning. This is the type of learning where a student learning without the instructor and away from the institute they are studying with. It is a conclusion in this paper that self-learning materials are very vital in self-directed learning because the learning materials need to be designed in ways that allows the students to learn on their own in the absence of an instructor. The study concludes that self-learning materials have unique characteristics. The study also concludes that Open Distance and e- 
learning designers have a variety of institutes that they have designed to fit the different environmental requirements and needs of the diverse students. Material developers should be professionally trained in order to be adequately prepared to develop high-quality self-learning materials.

\section{Recommendations}

The study recommends that self-learning materials be written in a conversational narrative style that will make the learners feel that they are interacting with an invisible teacher. The study also recommends that simple and clear language be used in preparing self-learning material to make communication effective as the use of difficult and ambiguous words and sentences makes the discussion complicated.

\section{References}

i. Albuquerque, U., \& Prasad, N. (2019). Education Through Distance Learning. http:// employmentnews.gov.in/ newemp/ MoreContentNew.aspx?n=SpecialContent\&k=78, (Accessed 04 February 2019.

ii. AlGhamdi, J. \& Junaidu, S. (2014, Jan 8). Emulating F2F for a Distance Learning environmen.. Retrieved from https:/ / www.researchgate.net/ publication/311987266_Instructional_Materials_Development_in_ODL_Achievem ents_Prospects_and_Challenges

https:// www.researchgate.net/ publication/ 311987266 Instructional Materials_Development in_ODL_Achievem ents_Prospects and Challenges ( Accessed 07 June 2019).

iii. Anh, D. H., Nishantha, G. G., Hayashida, Y., \& Davar, P. (2010). A flash-based lecture recording system and its integration with LMS. The 12th International Conference on Advanced Communication Technology (ICACT), pp. 1425-142 (Accessed 31 May 2019).

iv. Barandika, G., Beitia, J., Ruiz-de-Larramendi, I., \& Fidalgo, M. (2013). Design and Assessment of Self-Learning Material for the Subject Crystalline Solids: A Guide for Pharmacy Students Based On the Use ofthe Interne.. Proceedings of INTED2013 Conference 4th-6th March 2013 ,Valencia ,Spain.

v. Blaschke, L. (2014). Experiences in llff-determided Learning-Universitat Oldenburg. https:/ / uol.de/ fileadmin/ user upload/ coer/ Experiences-in-seld-determined-leanring.pdf, Accessed 03 May 2019.

vi. Boud, D., \& Falchikov, N. (2007). Rethinking Assessment in Higher Education: Learning fora Longer time. eds. Routledge Flamer, 270 Madison Ave, New York 1006, p.16.

vii. Briggs, S. (2015). 20 Steps towards More Self-Directed Learnin.. https:/ / www.opencolleges.edu.au/ informed/ features/ 29-steps-toward-more-self-directed-learning/ , (Accessed 03 May 2019).

viii. Brighter, M. (2017). Self-driven learning comes from a personal desire to gain new knowledge. https:/ / www.brightermonday.co.ke/ blog/ self-learning, (Accessed 03 May 2019).

ix. Chaudhary, S. V. S., \& Reddy, M. V. (2018). Unit-7 Design and Preparation of Self-Instructional Materials. IGNOU. HYPERLINK "http:/ / www.egyankosh.ac.in/ bitstream/ 123456789/ 47145/ 1/ Unit-7.pdf" http:/ / www.egyankosh.ac.in/ bitstream/ 123456789/ 47145/ 1/ Unit-7.pdf (Accessed 7 June 2019)

x. Chen Hsieh, J. S., Wu, W., \& Marek, M. (2017). Using the flipped classroom to enhance EFL learning. Computer Assisted Language Learning, 30(1-2), 1-21.

xi. Commonwealth of Learning (2005). Creating learning materials for Open and Distance Learning: A Handbook for authors and instructional designers.http:/ / oasis.col.org/ bitstream/ handle/ 11599/43/ odlinstdesignHB.pdf?sequence=1 \&isAllowed=y.. Creating learning materials for Open and Distance Learning: A Handbook for authors and instructional designers.http:/ / oasis.col.org/ bitstream/ handle/ 11599/ 43/ odlinstdesignHB.pdf?sequence=1 \&isAllowed=y, (Accessed 23 January 2019).

xii. Conrad, R, \& Donaldson, J. (2004). Engaging the online learner: Activities and resources for creative instruction .San Francisco: Jossey-Bass.

xiii. Dickson, K. ( 2018). 7 habits of the best self-directedlearners.. https:// bigthink.com/ personal-growth/ selfdirected-learning (Accessed 03 May 2019).

xiv. Dișlen, G., Ve, Ö., İfadeleri, Ö., Motivasyon, I., \& Sosyal, A. (2013). The reason for of lack of motivation from the students' and teachers' voices HYPERLINK "http://www.asosjournal.com/Makaleler/121323120_13\%20\%20G\%C3\%B6k\%C3\%A7e\%20Di\%C5\%9Flen.pdf"

http:/ / www.asosjournal.com/ Makaleler/ 121323120_13\%20-\%20G\%C3\%B6k\%C3\%A7e\%20Di\%C5\%9Flen.pdf . .(Accessed 8 June 2019)

xv. Dona, K. L., Gregory, J., \& Pechenkina, E. (2017). Lecture-recording technology in higher education: Exploring lecturer and student views across the disciplines. Australasian Journal of Educational Technology, 33(4) (Accessed on 22 May 2019).

xvi. Driscoll, M. P (2007). Psychological foundations of instructional design. In R. A.

xvii. Reiser \& J. V. Dempsey (Eds.), Trends and issues in instructional design and technology (pp. 36-44). Upper Saddle River, NJ: Pearson Education.

xviii. Endean, M. (2012). Learning Materials at a Distan. http:// www.materials.ac.uk/ guides/ distance.asp., (Accessed 08 May 2019).

xix. Ferriday, R. (2015). Innovative lecture capture. HYPERLINK "https:/ / core.ac.uk/ download/ pdf/ 42521441.pdf" https:/ / core.ac.uk/ download/ pdf/ 42521441.pdf (Accessed 8 June 2019) 
xx. Flood, M., Hayden, J. C., Bourke, B., Gallagher, P. J., \& Maher, S. (2017). Design and Evaluation of Video Podcasts for Providing Online Feedback on Formative Pharmaceutical Calculations Assessments. American journal of pharmaceutical education, 81(10)

xxi. Freeman, R. (2005). Creating learning materials for open and distance learning: a handbook for authors and instructional designers. Commonwealth of Learning (COL), (Accessed 6 June 2019).

xxii. Fry, H., Ketteridge, S., \& Marshall, S. (2008). A handbook for teaching and learning in higher education: Enhancing academic practi. . Routledge, Accessed 06 June 2019.

xxiii. Gazi, Z. A. (2009). Implementing constructivist approach into online course designs ina distance education institute at Eastern Mediterranean University. Turkish, Online Journal of Educational Technology, 8(2), 68-81.

xxiv. Gbenoba, F., \& Dahunsi, O. (2014). Instructional Materials Development in ODL: Achievements, Prospects anChallenges. . Journal of Educational and Social Research 4 (7), 138 143. .

xxv. Gosh, S., Nath, J., Agarwal, S., Nath, A., \& Chaudhuri, A. K. (2012). Open and distance learning (ODL) education system: past, present and future - a systematic study of an alternative education syst. https:/ / www.researchgate.net/ publication/ 276031945, (Accessed 02 February 2019).

xxvi. Graziano, K. J. (2017). Peer teaching in a flipped teacher education classroom. TechTrends, 61(2), 121-129.

xxvii. Hawkins, P. (2018) Self-directed learners. https:// paulinehawkins.com/tag/ self-directed-learners/ .(Accessed 7 June 2019)

xxviii. Hashim, Y. (2010). Open And Distance Learning (ODL) History and Concept. http:/ / citeseerx.ist.psu.edu/ viewdoc/ download;jsessionid=84D227F92ACD10D5D828CED0EFF461CF?doi=10.1. 1.175.5417\&rep=rep1\&type=pdf, (Accessed 18 January 2019).

xxix. Herreid, C. F., \& Schiller, N. A. (2013). Case studies and the flipped classroom. Journal of College Science Teaching, 42(5), 62-66.

xxx. Jayaram, D. (2019). Self-Learning Materials in Distance Educationhttps:/ / www.academia.edu/ 17912838/ Self Learning_Materials in Distance Education. . (Accessed 23 January 2019).

xxxi. Jayaram, K., \& Dorababu, K. (2015). Self-learning materials ithe $\mathrm{n}$ distance education syst,.. International Journal of Current Research, 7 (), , 21929-21934.

xxxii. Johri, A., \& Olds, B. M. (2014). Cambridge Handbook of Engineering Education Research.Cambridge; Cambridge University Press.

xxxiii. Jones, C. A. (2005). Assessment for Learni. https:/ / dera.ioe.ac.uk/ 7800/ 1/ AssessmentforLearning.pdf. .(Accessed 08 May 2019).

xxxiv. Kent, M., Ellis, K., Latter, N., \& Peaty, G. (2018). Captioning is a particularly useful and achievable instructional technique for subscribers of cognitivlearningni. The case for captioned lectures in Australian higher education TechTrends, 62(2), 158-165 (Accessed on 20 May 2019).

xxxv. Khalil, M. (2016). Applying learning theories and instructional design models for effective instruction. https:/ / www.physiology.org/ doi/ abs/ 10.1152/ advan.00138.2015, (Accessed 03 May 2019).

xxxvi. Kim, M. K., Kim, S. M., Khera, O., \& Getman, J. (2014). The experience of three flipped classrooms in an urban university: An exploration of design principles. The Internet and Higher Education, 37-50.

xxxvii. Koul, B. N., Ghaudhary, \& Sohanvir. (1989). Self-instructional course units IGNOU. . Handbook New Delhi: Indira Gandhi National Open University.

xxxviii. Krašna, M., \& Bratina, T. (2014). E-learning materials for social science students. Problems of education in the 21st century $61.77-87$.

xxxix. Kumar, P. (2016)The precisenessss of Self-Learning Material for Teacher Education in Special Education: Learners' Viewpoint. International Education \& Research Journal 2 (10), 34 - 35.

xl. Kumari, S. (2012). Factors affecting students' retention and attrition in the open and distance learning system. Indian Journal of Open Learning, 21 (1), 19-40.

xli. Kong, S. C. (2014). Developing information literacy and critical thinking skills through domain knowledge learning in digital classrooms: An experience opractisingng flipped classroom strategy. Computers \& Education, 78, 160173.(Accessed 8 June 2019)

xlii. Luque, D. (2017). Previously acquired cue-outcome structural knowledge guides new learning: Evidence from the retroactive-interference-between-cues effect. https:/ link.springer.com/ article/ 10.3758/ s13421-017-0705-4. , (Accessed 03 May 2019).

xliii. MacLeod, L., Bergen, A., \& Storey, M. A. (2017). Documenting and sharing software knowledge using screencas. . Empirical Software Engineering, 22(3), 1478-1507.

xliv. Mahlangu, V. P. (2018). The Good, the Bad, and the Ugly of Distance Learning in Higher Educati. . https:/ / www.intechopen.com/ ...learning/ the-good-the-bad-and-the-ugly-of-distance-le.., (Accessed 03 May 2019).

xlv. Mai, N.., Tse-Kian, N. Xiao-Lian, , G.T. (2007). A constructivist approach to

xlvi. learning an interactive multimedia course: Malaysian students' perspectives, Australasian Journal of Educational Technology, 23(4), 470-489

xlvii. Mart, C. T. (2011). How to sustain students' motivation in a learning environme. https:/ / files.eric.ed.gov/ fulltext/ ED519165.pdf. , (Accessed 03 May 2019).

xlviii. Mayer, R. E. (2009). Multimedia Learni. . Cambridge: Cambridge University Press. 
xlix. Minnesota State University (2019) Online Learning https://www.minnstate.edu/ online/ rightforyou.html (Accessed 8 June 2019)

l. Morrison, D. (2012). Five-step Strategy for Student Success with Online Learni. https:/ / onlinelearninginsights.wordpress.com/ 2012/ 09/ 28/ five-step-strategy-for-student-success-with-onlinelearning/ ., (Accessed 03 May 2019).

li. O'Neill, M. (2009). Podcasting in Academia: Exploring the challenges and opportunities of Podcasting for communication with students at Edinburgh Napier University. Wells ParCommunications. .

lii. Pappas, C. (2018). 8 Tips to Incorporate Screencasts Into Your Online Training Course. https:/ / www.techsmith.com/ blog/ screencasts-online-training-course/ (Accessed 8 June 2019)

liii. Peterson, E. (2007). Incorporating screencasts in online teaching. The International Review of Research in Open and Distributed Learning, 8(3) pp 1-5

liv. Rahman, M. (2015). Learning Assessment in A Self- Learning Material. International Journal on New Trends in Education and Their Implications 6 (3), 95 - 101.

lv. Rakes, G.C. \& Dunn, K.E. (2010). The impact of online graduate students' motivation and self-regulation on academic procrastination. Journal of Interactive Online Learning. 9 (1), 78-93.

lvi. Ramirez, G. M. (2012). Usage of Multimedia Visual Aids in the English Language Classroom: A Case Study at Margarita Salas Secondary School (Majadahonda). Unpublished Master thesis, Universitas Complvtensis. https:/ / www.ucm.es/ data/ cont/ docs/ 119-2015-03-17-11.MariaRamirezGarcia2013.pdf., (Accessed 8 June)

lvii. Roslinda, R., Asrina S., \& Siti, Z. (2017). A Review On The Innovative Use of Screencast Technique For Learning 3D AnimatioSoftware. . International Conference on Information Technology \& Society Julai 31st July \& August 1st, 2017, Penang, Malaysia 42, (Accessed on 27 May 2019).

lviii. Salmon, G., \& Edirisingha, P. (2008). Podcasting for Learning in Universities. Society for research into Higher Education. McGraw: Open UniversitPressss .

lix. Salmon, G., Edirisingha, P., Mobbs, M., Mobbs, R., \& Dennett, C. (2008). How to Create Podcasts for Education. McGraw: Open University Press.

lx. Seyed, G. (2012). The Impact of Self-directed Learning Strategies on Reading Comprehension. https:/ / www.researchgate.net/ publication/ 232660461 The Impact of Selfdirected Learning_Strategies_on_Reading_Comprehension. , (Accessed 03 May 2019).

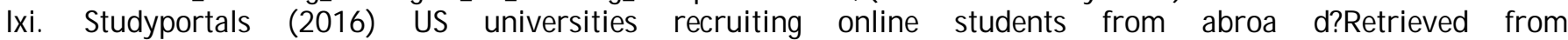
https:/ / www.studyportals.com/tag/ distance-learning/ (Accessed 03 May 2019).

lxii. Soto, M., \& Ambrose, R. (2016). Screencasts: Formative assessment for mathematical thinki. . Technology, Knowledge and Learning, 21(2), 277-283.

lxiii. Somuah, B. A., Dankyi, L. A., \& Dankyi, J. K. (2014). An investigation into the study habits of distance learners: implications for guidance ancounsellingng services. Mediterranean Journal of Social Sciences, 5(6), 273.

lxiv. Surbhi, S. (2014). Difference between Open University and Distance Education. https:/ / keydifferences.com/ difference-between-open-university-and-distance-education.html, (Accessed 03 May 2019).

lxv. Tarhan, L., \& Sesen, B. A. (2012). Jigsaw cooperative learningacid-basese theories. Chemistry Education Research and Practice, 13(3), 307-31 3.(Accessed 8 June 2018)

lxvi. Tezpur University. (2018). Development of Self Learning Materials for Open and Distance Mode of Learning. Retrieved from http:/ / www.tezu.ernet.in/ tu codl/ notification/ Report-SG.pdf (Accessed 7 June 2019)

lxvii. Thompson, B. (2003). Introduction to open learning and instructional design for open learning. Vancouver: Commonwealth of Learning (COL).

lxviii. Trembla, K., Lalancette, D., \& Roseveare, D. (2012). Assessment of higher education learning outcomes. http:/ / www.oecd.org/ education/ skills-beyond-school/ AHELOFSReportVolume1.pdf ., (Accessed 03 May 2019).

lxix. Tullis, J. G., \& Benjamin, A. S. (2011). On the effectiveness of self-paced learning. Journal of memory and language, 64(2), 109-11 8.(Accessed 8 June 2019)

lxx. UNISA. (2019). Open Distance Learning (ODL) is a different way of learning. https:/ / www.unisa.ac.za/ sites/ corporate/ default/ Apply-for-admission/ Honours-degrees- \&-postgraduatediplomas/ ODL,-Unisa-and-postgraduate-studies/ Open-Distance-Learning-(ODL)-is-a-different-way-of-learning , (02 February 2019).

lxxi. Wallis, C. (2017). A textbook dilemma: Digital or pap. . https:/ / hechingerreportorg/ textbook-dilemma-digitalpaper, (Accessed 23 January 2019).

lxxii. Willis, M. (2018). The Power of Curiosity. Self-Directed Education gives curiosity space to do its mag. . https:/ / www.self-directed.org/ tp/ power-of-curiosity/ , (Accessed 03 May 2019).

lxxiii. Yorke, M. (2003). Formative assessment in higher education: moves towards theory and the enhancement of pedagogic practice, Higher Education, 45(4): p.482

lxxiv. Zabidi, N., Woo, T., Kumar, R., Fadzil, M., \& Husain, S. (2017). Quality assurance in learning material development at OUM. Asian Association of Open Universities Journal, 12 (1), 69-81. 